BAKTIMAS

Jurnal Pengabdian pada Masyarakat
Vol. 1, No. 2,

Agustus 2019
eISSN 2685-113x

pISSN 2685-0303

\title{
Pengembangan Kawasan Konservasi Berbasis Etnozoologi bagi Masyarakat Sekitar Kawasan Cagar Alam "Leuweung Sancang".
}

\author{
Vita Meylani, Diki Muhamad Chaidir \\ Pendidikan Biologi FKIP Universitas Siliwangi Tasikmalaya Jawa Barat \\ e-mail korespondensi: vibriovita@unsil.ac.id
}

\begin{abstract}
Abstrak
Banyaknya eksploitasi dan perburuan terhadap flora dan fauna yang ada, termasuk di wilayah konservasi, merupakan suatu masalah di Indonesia. Salah satu hal yang dapat dilakukan untuk mengatasi hal tersebut adalah dengan mengembangkan konsep pariwisata yaitu wisata berkelanjutan atau ekowisata. Untuk mencapai tujuan pengabdian pada masyarakat tentang pengembangan kawasan konservasi berbasis etnozoologi bagi masyarakat sekitar kawasan Cagar Alam "Leuweung Sancang" metode yang digunakan adalah ceramah, diskusi, dan brainstorming. Pendekatan yang digunakan adalah pendekatan PRA (Participatory Rural Appraisal). Siklus dan tahapan pendekatan PRA yang digunakan terdapat beberapa tahapan yaitu tahapan persiapan, pelaksanaan, evaluasi dan refleksi. Melalui pendekatan dan memberikan pemahaman terhadap konsep wisata berbasis etnozoologi, diharapkan terbentuk sumber daya manusia yang memiliki pengetahuan dan keterampilan tambahan sebagai kader konservasi yang mampu mengelola kawasan konservasi menjadi nilai tambah secara ekonomi, sehingga keberadaan zona konservasi dirasakan manfaatnya baik secara ekonomi maupun ekologis.
\end{abstract}

Kata Kunci : etnozoologi, ekowisata

\section{PENDAHULUAN}

Indonesia merupakan negara berkembang yang terus melakukan pembangunan dan Pengembangan dalam berbagai aspek di setiap wilayahnya. Aspek utama yang dikembangkan adalah ekonomi dimana aspek ini diupayakan dapat meningkatkan taraf hidup dan perekenomian masyarakat. Untuk melakukan hal tersebut tidak terlepas dari berbagai upaya dalam meningkatkan sumber daya manusia dan memanfaatkan sumber daya alam yang ada. Akan tetapi pemanfaatan sumber daya alam yang berkelanjutan masih belum optimal serta cenderung hanya memanfatkan tanpa ada upaya dalam melakukan pelestarian terhadap lingkungan hidup yang berada di sekitar. Hal tersebut terlihat dengan masih banyaknya eksploitasi dan perburuan terhadap flora dan fauna yang ada, termasuk di wilayah konservasi. Salah satu hal yang dapat dilakukan untuk mengatasi hal tersebut adalah dengan mengembangkan konsep pariwisata yaitu wisata berkelanjutan atau ekowisata. Pariwisata dapat dikatakan sebagai suatu sistem yang memberikan kesempatan kepada wisatawan untuk dapat menikmati objek dan daya tarik wisata pada suatu wilayah. Sebagai sebuah sistem, pariwisata terdiri atas elemenelemen yang saling berinteraksi satu dengan yang lainnya secara terorganisir. Karena pariwisata merupakan bentuk perjalanan, maka tidak mungkin wisatawan dapat 
menikmati objek dan daya tarik wisata tanpa pelayanan dari biro perjalanan. Karena pariwisata juga untuk mendapatkan pengalaman, tidak mungkin wisatawan yang berkunjung mencapai kepuasan tanpa adanya profesionalitas pengelola objek dan daya tarik wisata. Ekowisata sendiri berbeda dengan konsep pariwisata pada umumnya, di dalam ekowisata lebih menciptakan keinginan membuat kepuasan sendiri tentang alam, tentang mengeksplorasi potensi wisata untuk konservasi dan pembangunan serta mencegah dampak negatifnya terhadap ekologi, kebudayaan dan keindahan (Western dalam Asmin, 2017). Salah satu konsep Pengembangan wisata berkelanjutan dapat dilakukan dengan mengembangkan ekowisata berbasis etnozoologi. Etnozoologi disini dapat dilihat dengan bagaimana suatu hubungan timbal balik antara hewan yang berada di wilayah setempat dengan masyarakat sekitar dilihat dari aspek budaya dan sosialnya (Setwayan, 2015).

Dengan peningkatan pemahaman masyarakat sekitar diharapkan masyarakat dapat mengubah pola perilaku dalam hal memanfaatkan atau berburu secara langsung hewan yang berada di wilayah tersebut tetapi lebih memanfatkan secara lestari. Salah satu manfaat yang dapat dirasakan adanya kehadiran hewan tertentu di wilayah tersebut adalah manfaat ekonomi secara tidak langsung berupa nilai eksistensi yang menjadi daya tarik tersendiri bagi wisatawan lokal maupun mancanegara ke wilayah tersebut. Desa sancang merupakan salah satu desa yang memiliki potensi ekowisata berbasis etnozoologi yang berbatasan langsung dengan kawasan konservasi cagar alam leuweung sancang. Masyarakat disana mempunyai kepercayaan sendiri terhadap beberapa hewan yang berada di hutan, salah satunya adalah kepercayaan masyarakat yang akan mengambil ranting jatuh yang sebelumnya dihinggapi oleh kalong akan dianggap sebagai pembawa keberuntungan. Selain itu kemunculan hewan lain seperti kukang yang masuk ke rumah warga dianggap sebagai pembawa sial atau musibah. Selain itu juga masih ada kepercayaan tentang beberapa hewan yang dapat dikonsumsi dijadikan sebagai obat. Manfaat obat yang berasal dari hewan yang belum terbukti secara ilmiah masih banyak dipercaya oleh masyarakat lokal, diantaranya daging biawak dan anak tikus yang masih dipercaya sebagai obat untuk sakit asma. Nilai penggunaan hewan sebagai obat yang digunakan untuk tujuan pengobatan dari dahulu dan masih digunakan sampai sekarang adalah bagian dari obat tradisional dan etnik, pengetahuan ini diperoleh dengan metode "trial and error" kemudian ditransfer dari generasi ke generasi (Kamble, 2014). Meskipun demikian masyakarat sekitar wilayah hutan sancang tidak menggantung seluruh kebutuhan protein hewaninya berasal dari tempat tersebut, karena sudah banyak masyarakat yang berternak hewan ternak maupun berkebun. Cagar alam leuweung sancang merupakan salah satu wilayah yang berada di selatan kabupaten Garut, Jawa Barat. Kawasan ini ditetapkan sebagai cagar alam dengan luas 2157 Ha berdasarkan SK Menteri Pertanian nomor 370/Kpts/Um/6/1978 tanggal 9 Juni 1978, sedangkan penunjukan Cagar Alam Laut berdasarkan SK Menteri Kehutanan No.682/Kpts-II/1990 tanggal 17 Nopember 1990 dengan luas 1.150 Ha memanjang dari muara sungai Cimerak sampai muara Sungai Cikaengang, dengan adanya cagar alam laut juga termasuk wilayah mangrove dan terumbu karang yang berada di wilayah tersebut (BBKSDA Jabar, 2016).

Berdasarkan hasil observasi dan wawancara dengan masyarakat sekitar, potensi fauna yang ada di wilayah tersebut sangat beragam, beberapa diantaranya terdapat jenis 
BAKTIMAS

Jurnal Pengabdian pada Masyarakat
Vol. 1, No. 2,

Agustus 2019
eISSN 2685-113x

pISSN 2685-0303

mamalia eksotik yaitu Macan tutul (Panthera pardus), Owa Jawa (Hylobates moloch), Lutung Jawa (Trachypithecus auratus) dan kukang jawa (Nycticebus javanicus), selain itu juga terdapat beberapa burung antara lain burung merak (Pavo muticus), Burung Julang (Aceros undulatus) dan burung elang laut dada putih (Haliaeetus leucogaster). Selain itu terdapat berbagai jenis hewan invertebrate lain yang sangat beragam seperti berbagai jenis kupu-kupu, serangga dan terumbu karang. Eksistensi dari hewan-hewan tersebut mempunyai nilai tambah tersendiri bagi kawasan terumbu karang Melalui pendekatan dan memberikan pemahaman terhadap konsep wisata berbasis etnozoologi, diharapkan terbentuk sumber daya manusia yang memiliki pengetahuan dan keterampilan tambahan sebagai kader konservasi yang mampu mengelola kawasan konservasi menjadi nilai tambah secara ekonomi, sehingga keberadaan zona konservasi dirasakan manfaatnya baik secara ekonomi maupun ekologis.

\section{METODE}

Untuk mencapai tujuan pengabdian pada masyarakat tentang pengembangan kawasan konservasi berbasis etnozoologi bagi masyarakat sekitar kawasan Cagar Alam "Leuweung Sancang" metode yang digunakan adalah ceramah, diskusi, dan brainstorming. Selain itu agar proses transfer pengetahuan dan keterampilan dapat lebih mudah pendekatan PRA (Participatory Rural Appraisal) yang lebih melibatkan partisipasi aktif dari mitra sehingga pelaksanaannya menjadi lebih efektif, sehingga keterlaksanaan dan keberlanjutan program bisa lebih matang dan berhasil.

Siklus dan tahapan pendekatan PRA yang digunakan terdapat beberapa tahapan yaitu tahapan persiapan, pelaksanaan, evaluasi dan refleksi. Pada tahap persiapan pengusul melakukan diskusi dan pengakraban diri dengan masyarakat lokal; bersama dengan mitra membentuk tim khusus; melakukan pengkajian data sekunder; penetapan tujuan dan perumusan rencana umum program; mengidentifikasi masalah dan kebutuhan yang ada di sekitar dan diminta untuk merumuskan dan menetapkan prioritas masalah yang ada dil lokasi. Tahap pelaksanaan, dimulai dengan pembahasan kembali maksud; tujuan dan perumusan rencana umum program; pemberian materi, pelatihan dan pengumpulan informasi bersama; Analisa dan pengolahan data fauna dan pemanfataannya yang ditemukan; berbagi informasi dan medokumentasikan hasil diskusi. Setelah itu dilakukan evaluasi terhadap seluruh kegiatan yang telah dilaksanakan dan melakukan refleksi untuk melihat apakah masyarakat sudah mendapatkan peningkatan pengetahuan dan keterampilan; apakah yang telah berhasil dipelajari hingga kegiatan sudah menjadi transformasi yang bergulir dan berkelanjutan.

\section{HASIL DAN PEMBAHASAN}

Indonesia merupakan negara berkembang yang terus melakukan pembangunan dan Pengembangan dalam berbagai aspek di setiap wilayahnya. Aspek utama yang dikembangkan adalah ekonomi dimana aspek ini diupayakan dapat meningkatkan taraf hidup dan perekenomian masyarakat. Untuk melakukan hal tersebut tidak terlepas dari berbagai upaya dalam meningkatkan sumber daya manusia dan memanfaatkan sumber 
daya alam yang ada. Akan tetapi pemanfaatan sumber daya alam yang berkelanjutan masih belum optimal serta cenderung hanya memanfatkan tanpa ada upaya dalam melakukan pelestarian terhadap lingkungan hidup yang berada di sekitar. Hal tersebut terlihat dengan masih banyaknya eksploitasi dan perburuan terhadap flora dan fauna yang ada, termasuk di wilayah konservasi. Salah satu hal yang dapat dilakukan untuk mengatasi hal tersebut adalah dengan mengembangkan konsep pariwisata yaitu wisata berkelanjutan atau ekowisata. Pariwisata dapat dikatakan sebagai suatu sistem yang memberikan kesempatan kepada wisatawan untuk dapat menikmati objek dan daya tarik wisata pada suatu wilayah. Sebagai sebuah sistem, pariwisata terdiri atas elemenelemen yang saling berinteraksi satu dengan yang lainnya secara terorganisir. Karena pariwisata merupakan bentuk perjalanan, maka tidak mungkin wisatawan dapat menikmati objek dan daya tarik wisata tanpa pelayanan dari biro perjalanan. Karena pariwisata juga untuk mendapatkan pengalaman, tidak mungkin wisatawan yang berkunjung mencapai kepuasan tanpa adanya profesionalitas pengelola objek dan daya tarik wisata. Ekowisata sendiri berbeda dengan konsep pariwisata pada umumnya, di dalam ekowisata lebih menciptakan keinginan membuat kepuasan sendiri tentang alam, tentang mengeksplorasi potensi wisata untuk konservasi dan pembangunan serta mencegah dampak negatifnya terhadap ekologi, kebudayaan dan keindahan (Western dalam Asmin, 2017). Salah satu konsep Pengembangan wisata berkelanjutan dapat dilakukan dengan mengembangkan ekowisata berbasis etnozoologi. Etnozoologi disini dapat dilihat dengan bagaimana suatu hubungan timbal balik antara hewan yang berada di wilayah setempat dengan masyarakat sekitar dilihat dari aspek budaya dan sosialnya (Setwayan, 2015).

Dengan peningkatan pemahaman masyarakat sekitar diharapkan masyarakat dapat mengubah pola perilaku dalam hal memanfaatkan atau berburu secara langsung hewan yang berada di wilayah tersebut tetapi lebih memanfatkan secara lestari. Salah satu manfaat yang dapat dirasakan adanya kehadiran hewan tertentu di wilayah tersebut adalah manfaat ekonomi secara tidak langsung berupa nilai eksistensi yang menjadi daya tarik tersendiri bagi wisatawan lokal maupun mancanegara ke wilayah tersebut. Desa sancang merupakan salah satu desa yang memiliki potensi ekowisata berbasis etnozoologi yang berbatasan langsung dengan kawasan konservasi cagar alam leuweung sancang. Masyarakat disana mempunyai kepercayaan sendiri terhadap beberapa hewan yang berada di hutan, salah satunya adalah kepercayaan masyarakat yang akan mengambil ranting jatuh yang sebelumnya dihinggapi oleh kalong akan dianggap sebagai pembawa keberuntungan. Selain itu kemunculan hewan lain seperti kukang yang masuk ke rumah warga dianggap sebagai pembawa sial atau musibah. Selain itu juga masih ada kepercayaan tentang beberapa hewan yang dapat dikonsumsi dijadikan sebagai obat. Manfaat obat yang berasal dari hewan yang belum terbukti secara ilmiah masih banyak dipercaya oleh masyarakat lokal, diantaranya daging biawak dan anak tikus yang masih dipercaya sebagai obat untuk sakit asma. Nilai penggunaan hewan sebagai obat yang digunakan untuk tujuan pengobatan dari dahulu dan masih digunakan sampai sekarang adalah bagian dari obat tradisional dan etnik, pengetahuan ini diperoleh dengan metode "trial and error" kemudian ditransfer dari generasi ke generasi (Kamble, 2014). Meskipun demikian masyakarat sekitar wilayah hutan sancang tidak menggantung seluruh kebutuhan protein hewaninya berasal dari 
BAKTIMAS

Jurnal Pengabdian pada Masyarakat
Vol. 1, No. 2,

Agustus 2019
eISSN 2685-113x

pISSN 2685-0303

tempat tersebut, karena sudah banyak masyarakat yang berternak hewan ternak maupun berkebun. Cagar alam leuweung sancang merupakan salah satu wilayah yang berada di selatan kabupaten Garut, Jawa Barat. Kawasan ini ditetapkan sebagai cagar alam dengan luas $2157 \mathrm{Ha}$ berdasarkan SK Menteri Pertanian nomor 370/Kpts/Um/6/1978 tanggal 9 Juni 1978, sedangkan penunjukan Cagar Alam Laut berdasarkan SK Menteri Kehutanan No.682/Kpts-II/1990 tanggal 17 Nopember 1990 dengan luas $1.150 \mathrm{Ha}$ memanjang dari muara sungai Cimerak sampai muara Sungai Cikaengang, dengan adanya cagar alam laut juga termasuk wilayah mangrove dan terumbu karang yang berada di wilayah tersebut (BBKSDA Jabar, 2016).

Berdasarkan hasil observasi dan wawancara dengan masyarakat sekitar, potensi fauna yang ada di wilayah tersebut sangat beragam, beberapa diantaranya terdapat jenis mamalia eksotik yaitu Macan tutul (Panthera pardus), Owa Jawa (Hylobates moloch), Lutung Jawa (Trachypithecus auratus) dan kukang jawa (Nycticebus javanicus), selain itu juga terdapat beberapa burung antara lain burung merak (Pavo muticus), Burung Julang (Aceros undulatus) dan burung elang laut dada putih (Haliaeetus leucogaster). Selain itu terdapat berbagai jenis hewan invertebrate lain yang sangat beragam seperti berbagai jenis kupu-kupu, serangga dan terumbu karang. Eksistensi dari hewan-hewan tersebut mempunyai nilai tambah tersendiri bagi kawasan terumbu karang Melalui pendekatan dan memberikan pemahaman terhadap konsep wisata berbasis etnozoologi, diharapkan terbentuk sumber daya manusia yang memiliki pengetahuan dan keterampilan tambahan sebagai kader konservasi yang mampu mengelola kawasan konservasi menjadi nilai tambah secara ekonomi, sehingga keberadaan zona konservasi dirasakan manfaatnya baik secara ekonomi maupun ekologis.

\section{PENUTUP}

Melalui pendekatan dan memberikan pemahaman terhadap konsep wisata berbasis etnozoologi, diharapkan terbentuk sumber daya manusia yang memiliki pengetahuan dan keterampilan tambahan sebagai kader konservasi yang mampu mengelola kawasan konservasi menjadi nilai tambah secara ekonomi, sehingga keberadaan zona konservasi dirasakan manfaatnya baik secara ekonomi maupun ekologis.

\section{Ucapan Terimakasih}

Ucapan terimakasih kami sampaikan kepada ketua Lp2MPMP Universitas Siliwangi.

\section{Daftar Pustaka}

Badan Pusat Statistik. 2016. Kecamatan Sariwangi dalam Angka 2016. Badan Pusat Statistik Kabupaten Tasikmalaya.

Satria, D. 2009. Strategi Pengembangan Ekowisata Berbasis Ekonomi Lokal dalam Rangka Program Pengentasan Kemiskinan di Wilayah Kabupaten Malang. Journal of Indonesian Applied Economics, 3(1): 34 - 47. 
Vita Meylani, Diki Muhamad Chaidir

Soehendera, D. 2001. P.R.A. - Participatory Research Appraisal dalam Pelaksanaan Pengabdian kepada Masyarakat, Modul Latihan. Antropologi Indonesia, 66: $100-104$.

Supriatna, A. 2014. Relevansi Metode Participatory Rural Appraisal dalam Mendukung Implementasi Undang-Undang Pemerintah Desa. Jurnal Lingkar Widyaiswara, 1(1): $39-45$.

Tanaya, D.R. dan Rudiarto, I. 2014. Potensi Pengembangan Ekowisata Berbasis Masyarakat di Kawasan Rawa Pening, Kabupaten Semarang. Jurnal Teknik PWK, 3(1): $71-81$. 